\title{
Evolution of limpet assemblages driven by environmental changes and harvesting in North Iberia
}

\author{
M. Muñoz-Colmenero ${ }^{1, *}$, P. Turrero ${ }^{2}$, J. L. Horreo ${ }^{1}$, E. Garcia-Vazquez $^{1}$ \\ ${ }^{1}$ Department of Functional Biology, University of Oviedo, C/ Julián Clavería s/n. 33006, Oviedo, Spain \\ ${ }^{2}$ Department of Geology, C/ Jesús Arias de Velasco s/n. 33005, Oviedo, Spain
}

\begin{abstract}
Two limpet species, Patella depressa and P. vulgata, are the most accessible molluscs in the upper intertidal shore on the coast of Asturias (Northern Spain) and have been consumed by humans for thousands of years, with evidence of harvesting-driven directional selection for size since the Palaeolithic. These 2 species are also highly sensitive to environmental conditions, $P$. depressa being in expansion under the current warming conditions. Our coalescent analyses of mitochondrial DNA suggest that both species are currently in a process of slow decline in population growth after experiencing a recent bottleneck, presumably enhanced by human exploitation. Over a wider temporal scale, the evolution of these species in Asturias seems associated with climate change, which seems to have driven their expansion across the studied zone. Current differential compositions of Patella assemblages associated with short-term differences in temperature on North Iberian coasts are consistent with the preferred conditions for each species. Human exploitation may have contributed to the most recent changes in limpet population diversity and morphology (size) at a short temporal scale, whilst climate would have caused long-term changes and would be responsible for most of their present population distribution.
\end{abstract}

KEY WORDS: Demographic trends · Environmental changes $\cdot$ Patella depressa $\cdot$ Patella vulgate Harvesting

\section{INTRODUCTION}

Climate is a major factor shaping wild populations (Dawson et al. 2011), e.g. through changes in the geographical distributions of temperature-sensitive species (Thomas et al. 2004), predator-prey relationships (Parmesan 2006), generation time (Gross 2011) and population structuring (Horreo et al. 2011), or through asynchrony of life histories by delayed or advanced migrations (Valiente et al. 2010), through replacement of a species by another with different environmental requirements (Erasmus et al. 2002, Wilson et al. 2007). In intertidal ecosystems, species diversity and composition change along with climate, more pronouncedly in the most recent decades (Helmuth et al. 2006).
Limpets of the genus Patella are intertidal species distributed from southern Africa to the Northwest Atlantic and western Indo-Pacific (Christiaens 1973). Ridgway et al. (1998) studied 9 species within this genus: Patella depressa, P. ulyssiponensis, P. rustica, $P$. vulgata, $P$. candei, $P$. lugubris, $P$. ferruginea, $P$. caerulea and $P$. pellucida. Except for the last one, which lives attached to subtidal algae in the subtidal zone, these species live attached to intertidal rocks (Sá-Pinto et al. 2005). Some species have recently expanded their range as a consequence of climate warming, like P. depressa (Hawkins et al. 2008) and P. rustica (Ribeiro et al. 2010). P. depressa exhibits an increasing abundance along English coasts in detriment to other species within limpet assemblages (Hawkins et al. 2008). 
In the Atlantic, Patella vulgata prefers boreal to cold-temperate environments, while $P$. depressa prefers subtropical to warm-temperate regions, yet the 2 species coexist from North Wales to the south of Portugal (Fretter \& Graham 1976). There seems to be interspecific competition between $P$. depressa and $P$. vulgata in the sympatric area, although stronger intraspecific competition allows their coexistence (Boaventura et al. 2002). If $P$. depressa has recently increased its relative abundance in Britain as a consequence of climate warming, it can be hypothesised that a similar and perhaps more pronounced shift has occurred in the more southern coasts of North Iberia.

Climate, however, is not the only factor affecting limpet species, and other main causes and directions of population modifications should be identified to adequately interpret current species trends. Anthropogenic influences may explain limpet abundance and distribution in the region: these animals have been heavily exploited by humans since the first settlements of hunter-gatherers, mainly for food (e.g. Morales et al. 1998, Gutiérrez-Zugasti 2011). If exploitation is too intense, it can drastically reduce population sizes and induce processes such as loss of genetic variability, changes in population structure and ultimately population decline and resource depression (Myers \& Worm 2003, Ward \& Myers 2005). Depression of the genus Patella after the intense exploitation in the past has already been described (see Mannino \& Thomas 2002 and references therein). When several species within an assemblage are exploited simultaneously, as was the case of limpets in the Iberian peninsula (e.g. Morales et al. 1998), substitution of one species by another can occur if one is overexploited, leaving part of its niche free to be occupied by other species (Wing \& Wing 2001, Tsahar et al. 2009). An association between the density of Upper Palaeolithic human populations and current limpet size has been detected in North Iberia, together with genetic variation losses in heavily populated areas, which have been interpreted as a signal of old human effect on limpet assemblages (Turrero et al. 2012). Today, limpets are exploited in this region not at a commercial scale but as a low-intensity (small scale) artisanal collection for domestic or local consumption. It is probable that the most intense effects of human harvesting on limpet populations occurred in prehistoric times, although this has not yet been demonstrated.

Given the distribution of the genus Patella, its sensitivity to climate change (Mieszkowska et al. 2005, Lima et al. 2006) and its history of past human exploitation in North Iberia, Patella assemblages in this region are likely to be good models for examin- ing the relative effect of climate and harvesting on population structuring and genetic diversity. The results can also help assess the current status of the species from this genus in the region and accommodate management regulations to real population biological units and status. Population diversity, structure and demographic trends will be inferred from Bayesian coalescent analyses of cytochrome oxidase I and 16S rDNA mitochondrial sequences, which are of great phylogeographic value for this genus (Sá-Pinto et al. 2005).

\section{MATERIALS AND METHODS}

\section{Study sites, temperature data and sampling}

This study was conducted in Asturias, a region in Northern Spain (from $43.3944^{\circ} \mathrm{N}, 4.57431^{\circ} \mathrm{W}$ to $\left.43.5471^{\circ} \mathrm{N}, 7.02304^{\circ} \mathrm{W}\right)$ with $\sim 354 \mathrm{~km}$ of shoreline, most of it steep and rocky. The climate of the region is temperate Atlantic, with mild winters, moderate summer temperatures and a uniform monthly rainfall distribution ( 85 $\mathrm{mm} \mathrm{mo}^{-1}$ ) (AEMET 2005).

Annual sea surface temperatures (SST) were obtained from the Giovanni online data system (http:// modis.gsfc.nasa.gov), developed and maintained by the NASA Goddard Earth Sciences Data and Information Services Center (Acker \& Leptoukh 2007). We used monthly data from January 2007 to January 2010. The same application can calculate the averages and plots the dates for the study area (Fig. 1).

In Asturias, ongoing artisanal shellfishing is widespread along its coast, without apparent zone differences. We assume the preferential consumption of large individuals. Therefore, differences in exploitation, if any, will be based on size (targeting larger individuals over smaller ones) but not on sampling point or sampled area.

Limpet samples were collected at random from wave-exposed rocks in the upper tidal level of 9 beaches: from west to east, Figueras, Porcía, Luarca, San Pedro, Gijón, La Griega, La Atalaya, Cuevas del Mar and La Franca (Fig. 1). The samples were stored in $100 \%$ ethanol and transported to the laboratory for measuring maximum shell diameter and DNA extraction.

\section{Archaeological data sources}

Exploited limpet assemblages in different time periods are described by 2 reports on the marine 

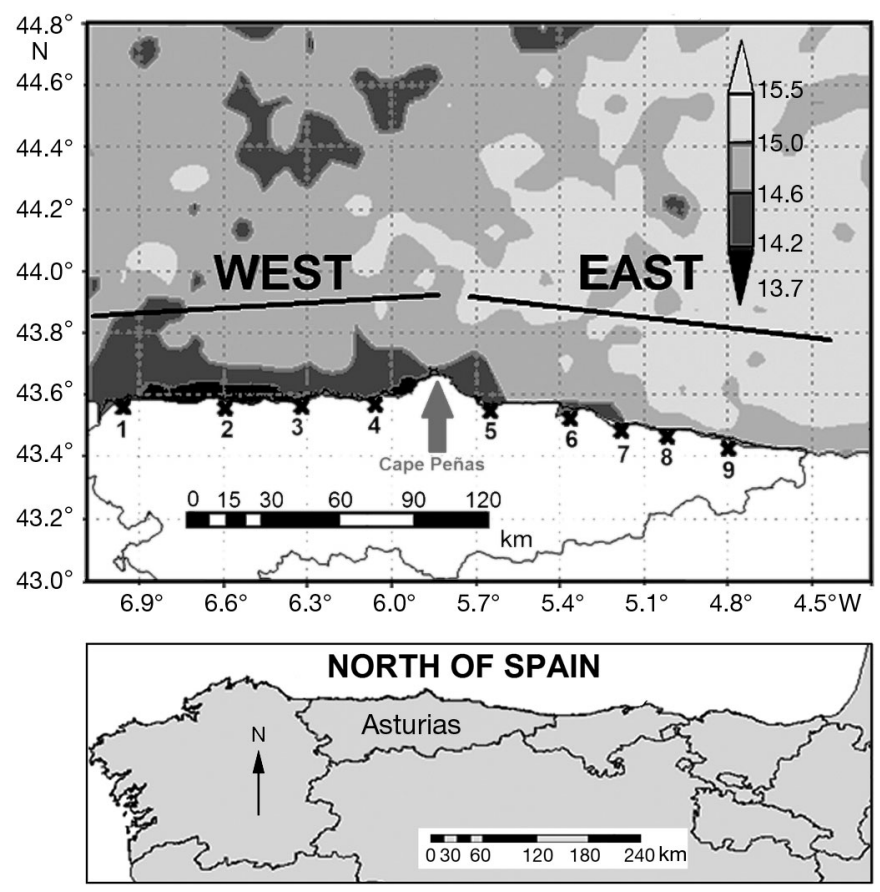

Fig. 1. Sea surface temperature along the coast of Asturias (Northern Spain), averaged from January 2007 to January 2010. $\mathbf{X}=$ sampling point (1: Figueras, 2: Porcia, 3: Luarca, 4: San Pedro, 5: Gijón, 6: La Griega, 7: La Atalaya, 8: Cuevas del Mar, 9: La Franca)

faunas of 2 archaeological sites at species level, Poza l'Egua (Arias Cabal et al. 2007) and La Riera (Ortea 1986), located near Cuevas del Mar and La Atalaya, respectively. The 2 sites contain identified limpets dated to the Magdalenian (ca. 16000 to $12000 \mathrm{yr}$ before present [BP]), Azilian (ca. 12000 to 8000 yr BP) and Asturian (ca. 9000 to 6000 yr BP) technological periods. Sample sizes for La Riera were 590, 7648 and 1109 limpet shells from the Magdalenian, Azilian and Asturian periods, respectively, and 25, 51 and 241 for the same periods in Poza l'Egua. The exploited species were reported in the original articles as Patella vulgata and P. intermedia. The scientific name of $P$. intermedia has been updated here to $P$. depressa following state-of-the-art taxonomic nomenclature for internal consistency.

\section{DNA extraction, amplification, purification and sequencing}

DNA extraction was carried out following a resinbased Chelex protocol (Estoup et al. 1996) from a portion of $\sim 2 \mathrm{~mm}$ of foot muscle dissected from each specimen. Polymerase chain reaction (PCR) amplification was performed for a fragment of the subunit I of the mitochondrial gene cytochrome c oxidase (COI) and a fragment of the 16S rRNA gene. The primer pairs COI-H-2198 and COI-1490-L were used for COI, with the conditions and reaction protocols described by Folmer et al. (1994); 16S rDNA was amplified using primer pairs 16LRN13398 and 16SRHTB as described by Koufopanou et al. (1999). PCR products were visualized and purified from a $2 \%$ agarose gel with a kit by Promega (Wizard SV Gel and PCR Clean-Up System). DNA fragments were sequenced using the ABI Prism BigDye Terminator Cycle sequencing protocol on an ABI Prism 3130 Automated Sequencer at the Unit of Genetic Analysis at the University of Oviedo.

\section{Population structuring analysis}

Sequences were visualized and edited using the BioEdit Sequence Alignment Editor software (Hall 1999). The sequences of each gene were aligned with the MUSCLE program included in the MEGA package (Tamura et al. 2011) and were compared with international databases employing the program nBLAST within NCBI (www.ncbi.nlm.nih.gov/). Species assignation was made based on $>99 \%$ sequence similarity with GenBank voucher specimens of Patella species.

The 16S rRNA and COI sequences were concatenated using the DnaSP software version 5.10 (Librado \& Rozas 2009) after an incongruence length differences (ILD) test was applied with the program PAUP version 4.0b10 (Swofford 2003) to check if the analysis of the 2 sequences together was congruent. Although this test is controversial for relatively recently evolved taxa (e.g. Yoder et al. 2001), it has been considered to be adequate for phylogenetically old taxa, like molluscs (e.g. Vonnemann et al. 2005).

The program ARLEQUIN version 3.5 (Excoffier et al. 2005) was used to calculate the following diversity parameters: number of haplotypes (Nh, haplotype being each mitochondrial sequence variant), haplotype diversity $(\mathrm{Hd}$, the probability of randomly choosing 2 different haplotypes from the sample) and nucleotide diversity $(\pi$, the mean of the nucleotide differences between all pairs of haplotypes in the sample). The same software was used to estimate genetic differentiation between pairs of populations $\left(F_{\mathrm{ST}}\right)$, measuring the significance of differences in haplotype frequencies between 2 samples, and to perform an analysis of molecular variance (AMOVA) to compare genetic variation between areas within the studied region (i.e. eastern versus western). The latter analysis calculates the percentage of variance 
accounted for by the differences between groups of samples (for example, between regions), between samples within groups and within samples and gives their statistical significance. ARLEQUIN was also used to check whether there is a relationship between genetic distances (measured by $F_{\mathrm{ST}}$ ) and geographic distances (in $\mathrm{km}$ ) with a Mantel test.

Haplotype networks were constructed with the software NETWORK version 4.6.0.0 (www.fluxusengineering.com). In these networks, different haplotypes are represented by circles connected by lines, which represent the mutations separating them. The diameter of each circle is proportional to the frequency of the corresponding haplotype.

\section{Estimates of demographic trends}

We used the concatenated sequences to analyse demographic trends at the species and regional level, separating the coastal areas at the east and west of Cape Peñas (see Fig. 1). The models of nucleotide substitution were obtained separately for each species and gene with the program jModelTest 0.1.1 (Posada 2008) with the Akaike information criterion (AIC). Chronological trends of population growth were retro-estimated employing the program BEAST for Bayesian Monte Carlo Markov Chain analysis of DNA sequences. This software is a framework for testing timemeasured phylogenies and performing coalescent analyses; amongst the analyses, it estimates population growth rates across time. We used version 1.6.1 (Drummond \& Rambaut 2007), with $0.5 \%$ per nucleotide per million years (Myr) as the mutation rate, following Calderon et al. (2008). The results of the BEAST analysis were visualized with the program Tracer v.1.5 (Rambaut \& Drummond 2007 and http://tree.bio.ed.ac.uk/software/ tracer) to check their stability: the reliability of the estimates was marked as colours (only parameter estimates appearing in black in a run are reliable, i.e. stable, and these were the only ones retained for this study). From the Excel output file provided by the BEAST program, growth rate graphics were constructed with the Microsoft Excel software.

The tree model used in the BEAST program was the Extended Bayesian Skyline Plot. The length of the Monte Carlo Markov Chain was $2.5 \times 10^{6}$ for the western samples of Patella depressa and $2 \times 10^{8}$ for the eastern ones (these lengths yielded stable results marked in black by the program Tracer). In the case of Patella vulgata, these lengths were $5 \times 10^{7}$ and $6.5 \times 10^{6}$ for eastern and western samples, respectively. In all cases, the first $10 \%$ of the chains were discarded as burn-in.

\section{RESULTS}

\section{Regional limpet species distribution}

Differences in sea surface temperature (SST) are evident in the studied regions west and east of Cape Peñas, being warmer in the east (Fig. 1). A total of 150 limpets (Table 1) were analysed from 4 points located west of Cape Peñas, in the colder part of the studied region $\left(13.7\right.$ to $\left.14.6^{\circ} \mathrm{C}\right)$, and 187 limpets from 5 points to the east, in the warmer part $\left(14.6\right.$ to $15.5^{\circ} \mathrm{C}$ ) (Fig. 1).

The 16S rDNA sequences are available in GenBank under accession numbers JF682557 to JF682592, JF682593 to JF682608 and JF758500 for Patella depressa, P. vulgata and P. rustica, respectively, and were already published by Turrero et al. (2012). The COI sequences for $P$. depressa, $P$. vulgata and $P$. rus-

Table 1. Genetic variability of concatenated sequences of the $16 \mathrm{~S}$ rRNA and COI genes for Patella vulgata and P. depressa sampled in 2010 from North Iberia. n: sample size (number of individuals in each population); Nh: number of haplotypes; $\mathrm{Hd}$ : haplotype diversity; $\pi$ : nucleotide diversity. -: low number of individuals or none at all

\begin{tabular}{|c|c|c|c|c|}
\hline & $\mathrm{n}$ & $\mathrm{Nh}$ & $\mathrm{Hd} \pm \mathrm{SD}$ & $\pi \pm \mathrm{SD}$ \\
\hline \multicolumn{5}{|l|}{ Patella vulgata } \\
\hline \multicolumn{5}{|l|}{ West } \\
\hline Figueras & 18 & 8 & $0.6405 \pm 0.1300$ & $0.000802 \pm 0.000656$ \\
\hline Porcía & 36 & 11 & $0.4841 \pm 0.1041$ & $0.000749 \pm 0.000608$ \\
\hline Luarca & 28 & 13 & $0.6825 \pm 0.1013$ & $0.001159 \pm 0.000834$ \\
\hline San Pedro & 13 & 6 & $0.6410 \pm 0.1498$ & $0.000971 \pm 0.000767$ \\
\hline \multicolumn{5}{|l|}{ East } \\
\hline Gijón & 14 & 9 & $0.8352 \pm 0.1008$ & $0.001803 \pm 0.001213$ \\
\hline La Griega & 3 & 1 & - & - \\
\hline La Atalaya & 1 & 1 & - & - \\
\hline La Franca & 2 & 2 & - & - \\
\hline \multicolumn{5}{|l|}{ Patella depressa } \\
\hline \multicolumn{5}{|l|}{ West } \\
\hline Figueras & 19 & 11 & $0.8772 \pm 0.0593$ & $0.002823 \pm 0.001712$ \\
\hline Porcía & 1 & 1 & - & - \\
\hline Luarca & 10 & 7 & $0.8667 \pm 0.1072$ & $0.002375 \pm 0.001565$ \\
\hline San Pedro & 19 & 14 & $0.9357 \pm 0.0472$ & $0.002500 \pm 0.001547$ \\
\hline \multicolumn{5}{|l|}{ East } \\
\hline Gijón & 24 & 10 & $0.7464 \pm 0.0907$ & $0.001769 \pm 0.001158$ \\
\hline La Griega & 27 & 15 & $0.9174 \pm 0.0377$ & $0.002501 \pm 0.001522$ \\
\hline La Atalaya & 43 & 21 & $0.8206 \pm 0.0582$ & $0.001771 \pm 0.001137$ \\
\hline Cuevas del Mar & 5 & 4 & $0.9000 \pm 0.1610$ & $0.001993 \pm 0.001536$ \\
\hline La Franca & 38 & 20 & $0.8620 \pm 0.0528$ & $0.001917 \pm 0.001214$ \\
\hline
\end{tabular}




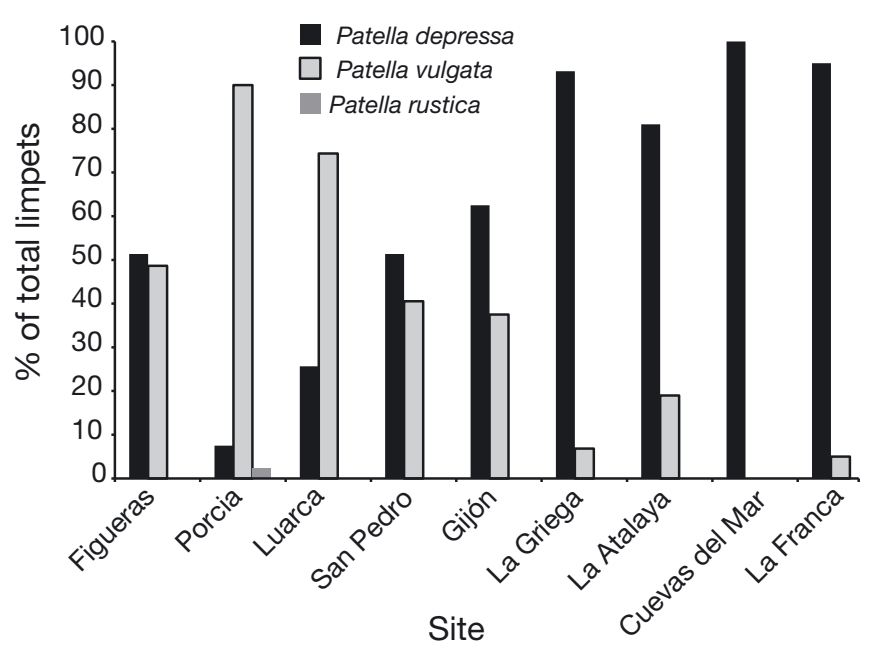

Fig. 2. Percentages of each limpet species at each sampling point (west to east)

tica are available in GenBank under accession numbers JF937113 to JF937160, JF937161 to JF937190 and JF937191, respectively. These sequences allowed the unambiguous identification to species level of all of the analysed individuals. The relative proportion of each species was not the same for all sampling sites (Fig. 2). P. vulgata was more abundant in western than eastern rocky beaches, whereas $P$. depressa showed the opposite spatial trend, being much more abundant than $P$. vulgata in eastern zones. Only 1 specimen of $P$. rustica appeared, in Porcía (western area).

The archaeofaunal analysis at species level considered in the present study concerns archaeological sites located near Cuevas del Mar and La Atalaya, in the eastern part of the region, where Patella depressa is now more abundant. A clear chronological trend is apparent (Fig. 3), wherein the abundance of $P$. vulgata decreased during the studied period in the 2 sites, even down to being absent from Cuevas del Mar today, with the corresponding increase of $P$. depressa. The average size of the archaeological

Table 2. Maximum shell diameter (mean $\pm \mathrm{SD}, \mathrm{n}=$ sample size) of North Iberian Patella depressa and P. vulgata west (W) and east (E) of Cape Peñas (archaeological data taken from Turrero et al. 2012)

\begin{tabular}{|lllcc|}
\hline Time period (yr) & Species & & Shell diameter $(\mathrm{cm})$ & $\mathrm{n}$ \\
\hline 16000-12000 BP & Patella sp. & & $4.16 \pm 0.74$ & 615 \\
$12000-8000 \mathrm{BP}$ & Patella sp. & & $3.88 \pm 0.75$ & 7699 \\
9000-6000 BP & Patella sp. & & $2.78 \pm 0.62$ & 1350 \\
Present & P. depressa & W & $2.66 \pm 0.44$ & 49 \\
& & E & $2.41 \pm 0.70$ & 137 \\
& P. vulgata & W & $2.87 \pm 0.39$ & 95 \\
& & E & $2.32 \pm 0.48$ & 20 \\
\hline
\end{tabular}

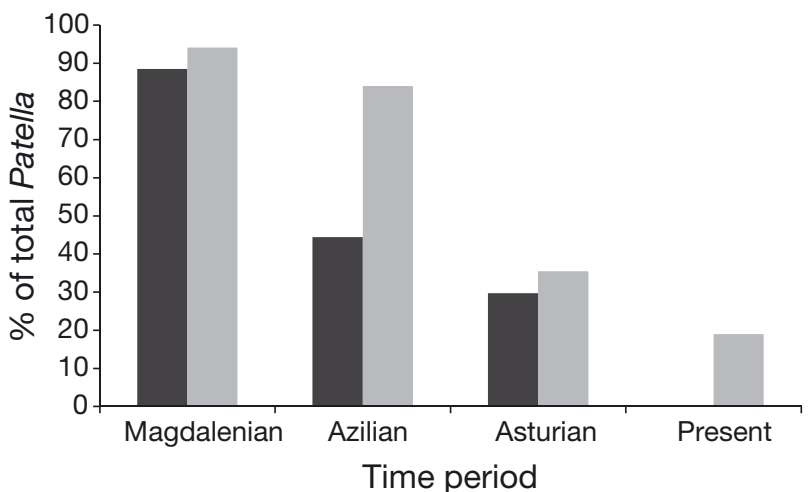

Fig. 3. Percentage of Patella vulgata of the total number of Patella shells found in 3 Upper Palaeolithic periods (faunal remains from nearby archaeological sites) and in modern samples, in Cuevas del Mar ( $($ ) and La Atalaya ( $($ ) (North Iberia). Total sample sizes for Cuevas del Mar are 25, 51, 241 and 5 for the Magdalenian, Azilian, Asturian and present periods, respectively, and 590, 7648, 1109 and 43, respectively, for La Atalaya

limpets (Table 2) significantly decreased with time ( $p<0.001$ for all $t$-tests between consecutive time periods), and modern individuals of the 2 species were smaller in the east than in the west of the Asturian distribution ( $\mathrm{p}<0.05$ for all $t$-tests) (for more details, see Turrero et al. 2012).

\section{Genetic variation}

For the 16S rDNA gene, 53 different haplotypes were found, 36 of which (found in 186 ind.) corresponded to Patella depressa (454 base pairs [bp]), 16 (115 ind.) to $P$. vulgata (453 bp) and 1 to the only $P$. rustica specimen (452 bp). Insertions/deletions were not found for any haplotype within the same species. For the COI gene, 79 haplotypes were obtained: 48 for P. depressa (650 bp), 30 for P. vulgata (656 bp) and 1 for $P$. rustica $(670 \mathrm{bp})$ specimen. Within-species polymorphism in sequence length was not found for this gene.

In the ILD test, the p-values obtained for Patella depressa and $P$. vulgata were nonsignificant (0.96 and 0.57 , respectively), indicating that the degree of incongruence between $16 \mathrm{~S}$ rDNA and COI sequences was not very high and that in the present case study, they could be concatenated. The concatenated sequences of the 2 genes were $1104 \mathrm{bp}$ long for P. depressa and $1109 \mathrm{bp}$ long for P. vulgata and yielded 71 and 42 different haplotypes, respectively. Lower nucleotide diversity was found in the east than in the west of the studied region (Table 1), and the trend was more pronounced for $P$. vulgata than for 
P. depressa. The $F_{\mathrm{ST}}$ values for each pair of populations were not statistically significant in any case (Table 3). The AMOVA indicated that the main component of the molecular variance was within-sample variation $(99.4 \%$ for $P$. vulgata and almost $100 \%$ for $P$. depressa), the regional (between east and west) and among-sample components being not significant. The absence of spatial differentiation was also reflected in an absence of correlation between geographical and genetic distances in the Mantel test $(\mathrm{r}=-0.153, \mathrm{p}=0.366$ and $\mathrm{r}=0.002, \mathrm{p}=0.981$ for $P$. depressa and $P$. vulgata, respectively).

\section{Demographic trends}

Haplotype networks showed 1 more frequent haplotype and a large number of unique haplotypes (carried by only 1 specimen) or haplotypes at low frequencies for the 2 species (Fig. 4). Low-frequency haplotypes were found mainly east of Cape Peñas for Patella depressa, while for $P$. vulgata, the opposite trend was found, with more unique haplotypes in the western region.

The model of nucleotide substitution that best fitted Patella vulgata sequences (for both genes) was HKY, which gives different frequencies for A-G and $\mathrm{C}-\mathrm{T}$ changes. The model $\mathrm{HKY}+\mathrm{I}+\mathrm{G}$ best fitted the 2 genes for $P$. depressa; it incorporates a proportion of invariable sites (I) and a rate of variation among sites with a number of rate categories $(G ; 4$ categories in this case). The corresponding model was therefore applied to the concatenated sequences of each species, and the population growth rates exhibited different temporal trends for the 2 species (Fig. 5). In $P$. depressa, maximum growth was first in the west $>125000$ yr BP, while in the eastern region, it occurred $\sim 100000$ yr BP. For P. vulgata, the situation was the opposite, with a growth rate peaking first in the eastern coast of Asturias $>180000 \mathrm{yr}$ BP and later in the west, $\sim 50000 \mathrm{yr}$ ago. For both species, the expansive population growth decreased after the marked peak in each region. Since before the Magdalenian period, population growth rates of the 2 species appear to have been decreasing at both sides of Cape Peñas over the years, albeit with a gentle slope (see detailed plots in Fig. 5).

\section{DISCUSSION}

Despite relatively small sample sizes in some points, the results presented here allowed us to determine population features of the studied species and to infer the effects of environmental conditions and harvesting. We have primarily found 2 of the 4 species recognized in the region (Borrell et al. 2010), Patella vulgata and P. depressa. P. ulyssiponensis is located at lower tidal levels (Sella et al. 1993), and although $P$. rustica is also found in the upper intertidal, only 1 individual was collected (in the western zone, in accordance with its distribution, supposedly mainly at the westernmost part of the region) (Borrell et al. 2010). No significant population differentiation was found for these limpets, which is consistent with a high dispersal capacity in larval periods (Johnson \& Black 1984).

Spatial differences in the relative abundance of the 2 species may reflect different environmental conditions. Cape Peñas represents a temperature boundary within the North Iberian Cantabrian coast, colder to the west than to the east (Fig. 1) due to western upwelling (Dickson \& Hughes 1981, Rios et al. 1987). Temperature affects these species in many ways, from determining gonad development (Orton et al. 1956, Bowman \& Lewis 1986) to promoting changes in phe-

Table 3. $F_{\mathrm{ST}}$ values between pairs of samples as indicators of population genetic differentiation. Patella depressa and $P$. vulgata are above and below the diagonal, respectively. No significant values were found. -: low number of individuals or none at all (Cuevas del Mar not shown since this applied to all comparisons for this site)

\begin{tabular}{|c|c|c|c|c|c|c|c|c|}
\hline & Figueras & Porcía & Luarca & $\begin{array}{c}\text { San } \\
\text { Pedro }\end{array}$ & Gijón & $\begin{array}{c}\mathrm{La} \\
\text { Griega }\end{array}$ & $\begin{array}{c}\text { La } \\
\text { Atalaya }\end{array}$ & $\begin{array}{c}\mathrm{La} \\
\text { Franca }\end{array}$ \\
\hline Figueras & & - & -0.03037 & 0.00016 & -0.00084 & -0.01647 & 0.01773 & 0.02235 \\
\hline Porcía & -0.00079 & - & - & - & - & - & - & - \\
\hline Luarca & -0.00357 & 0.0014 & - & -0.03404 & -0.02428 & -0.02637 & -0.00005 & -0.02328 \\
\hline San Pedro & -0.00674 & 0.00391 & $-0 . \overline{00818}$ & - & 0.00799 & 0.00062 & 0.02411 & 0.02193 \\
\hline Gijón & 0.00086 & 0.01857 & 0.00854 & $-0 . \overline{00} 17$ & - & -0.00747 & -0.01401 & -0.01456 \\
\hline La Griega & - & - & - & - & - & - & 0.00706 & 0.00103 \\
\hline La Atalaya & - & - & - & - & - & - & - & -0.00202 \\
\hline La Franca & - & - & - & - & - & - & $\overline{-}$ & - \\
\hline
\end{tabular}




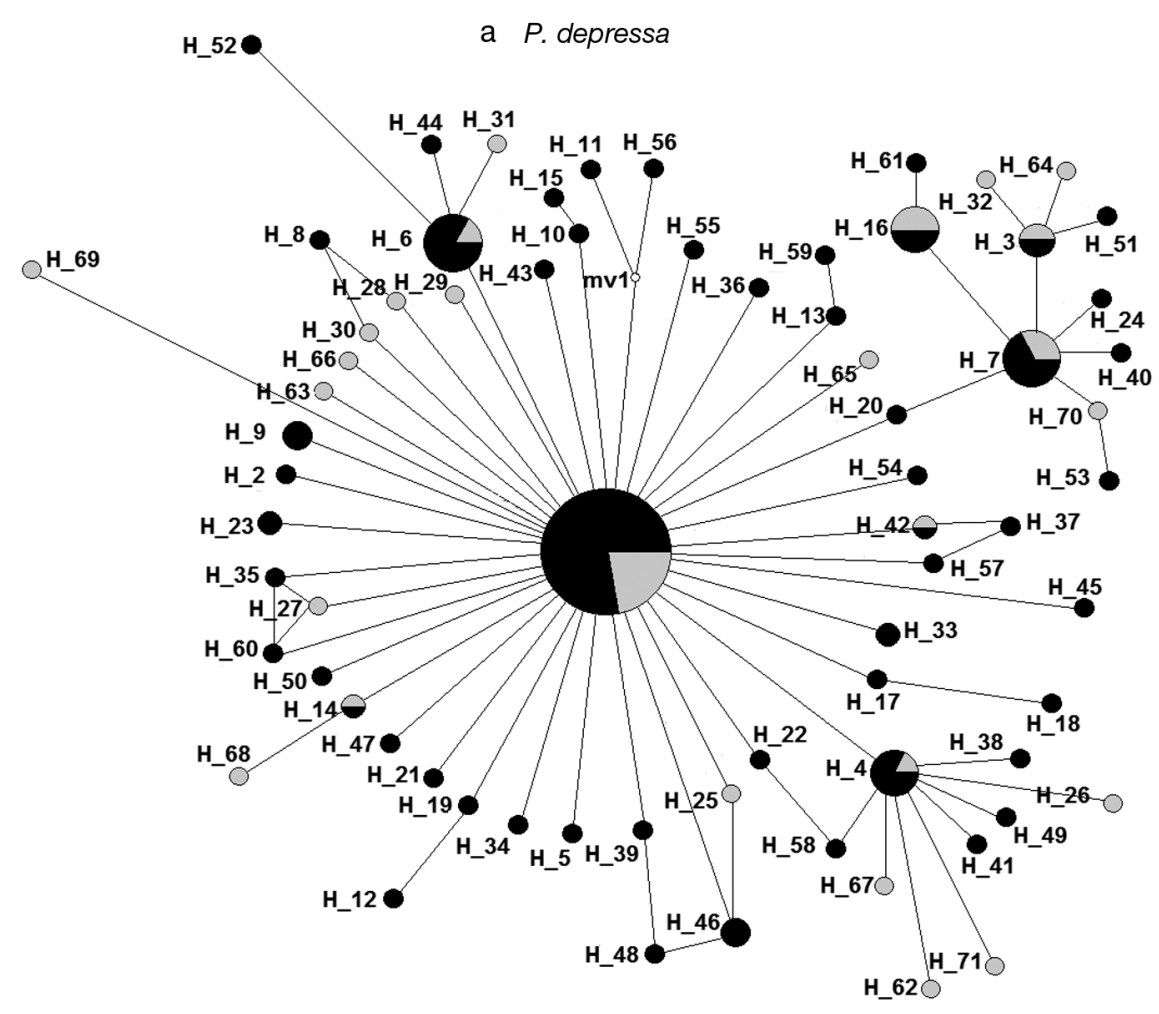

b P. vulgata

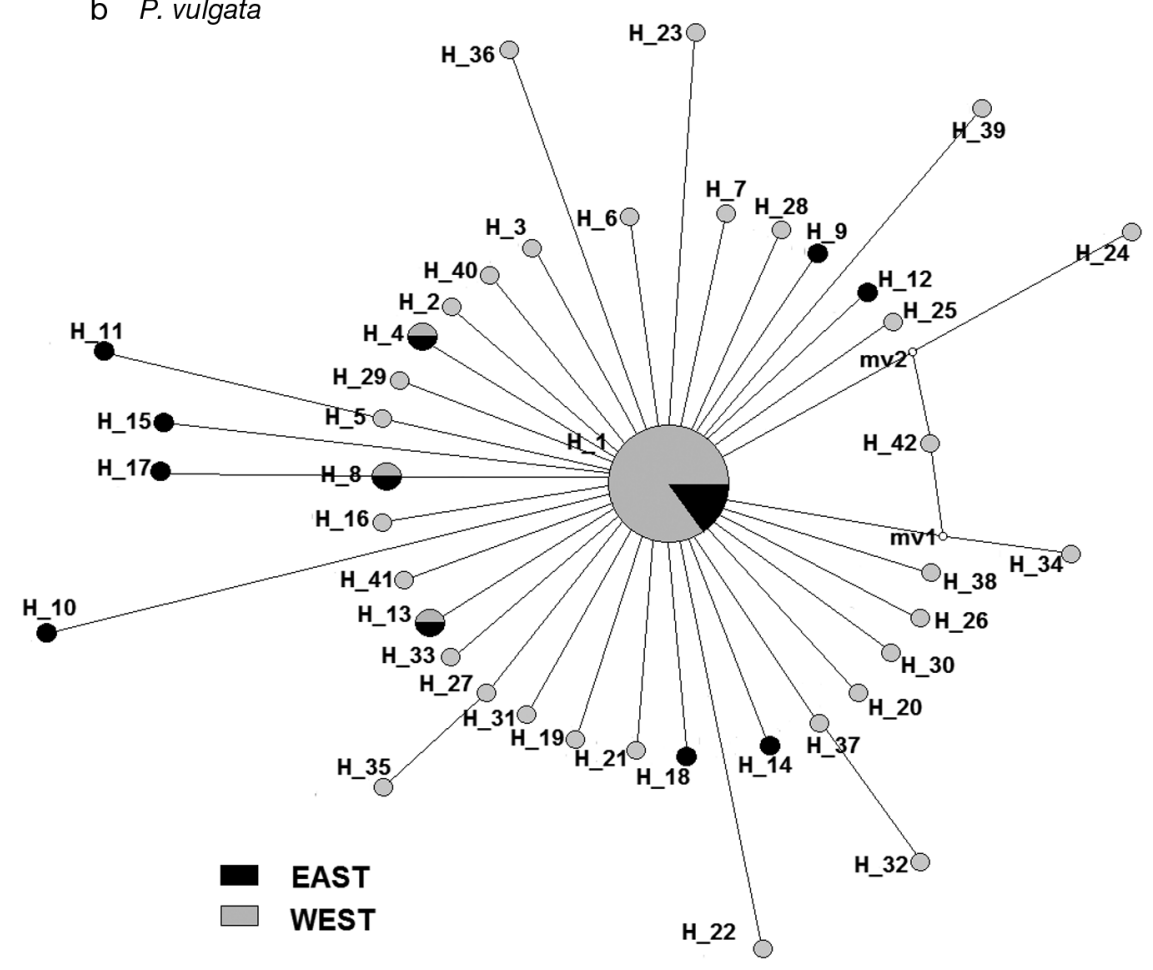

Fig. 4. Haplotype networks for (a) Patella depressa and (b) P. vulgata from Asturias, North Iberia, based on concatenated mitochondrial DNA sequences (16S DNAr + COI gene; see text). Sampling sites: east and west of Cape Peñas. The hypothetical intermediate haplotypes supposedly existing in the past to explain present variants are shown as white circles nology (Moore et al. 2011). Low temperatures are a cue for Patella vulgata gonadal development; the west of Cape Peñas, with lower temperatures, would therefore be more advantageous for this species and explain its greater abundance in this area.

The long-term demographic evolution of these limpets could be interpreted in terms of climatic fluctuations. For Patella depressa, expansive growth would have been initiated in the west (Fig. 5C), in agreement with current limpet assemblages of Portuguese shores, where $P$. depressa is the most common species (Boaventura et al. 2002). According to the BEAST results, such expansion coincided with a time of rising temperatures ( 125000 yr BP) (e.g. de Abreu et al. 2003, Toucanne et al. 2009), which is consistent with the climatic preferences of this species. In contrast, the pattern and timing of demographic expansion inferred for $P$. vulgata would have started at the east (Fig. 5B), with an explosive growth rate increase 180000 yr BP. The temperature seems to have dropped during this period (e.g. de Abreu et al. 2003, Toucanne et al. 2009), which is consistent with the preference of this species for colder temperatures. Its expansion in the west of the region would have occurred much later, $\sim 70000 \mathrm{yr}$ $\mathrm{BP}$, reaching its peak of population growth rate $\sim 50000$ yr ago; this moment also coincided with a descent of temperatures (e.g. de Abreu et al. 2003, Toucanne et al. 2009).

In the last 10000 yr BP, rapid climate fluctuations have occurred, with temperatures sometimes above the present average in the NE Atlantic (e.g. Davis et al. 2003). As a consequence, rapid changes in species assemblages of rocky shore ecosystems have been reported, with increases in some species and marked decreases in others (Herbert et al. 2003, 2007, Lima et al. 2006, 2007, Hawkins et al. 2008). Fluctuating environmental 

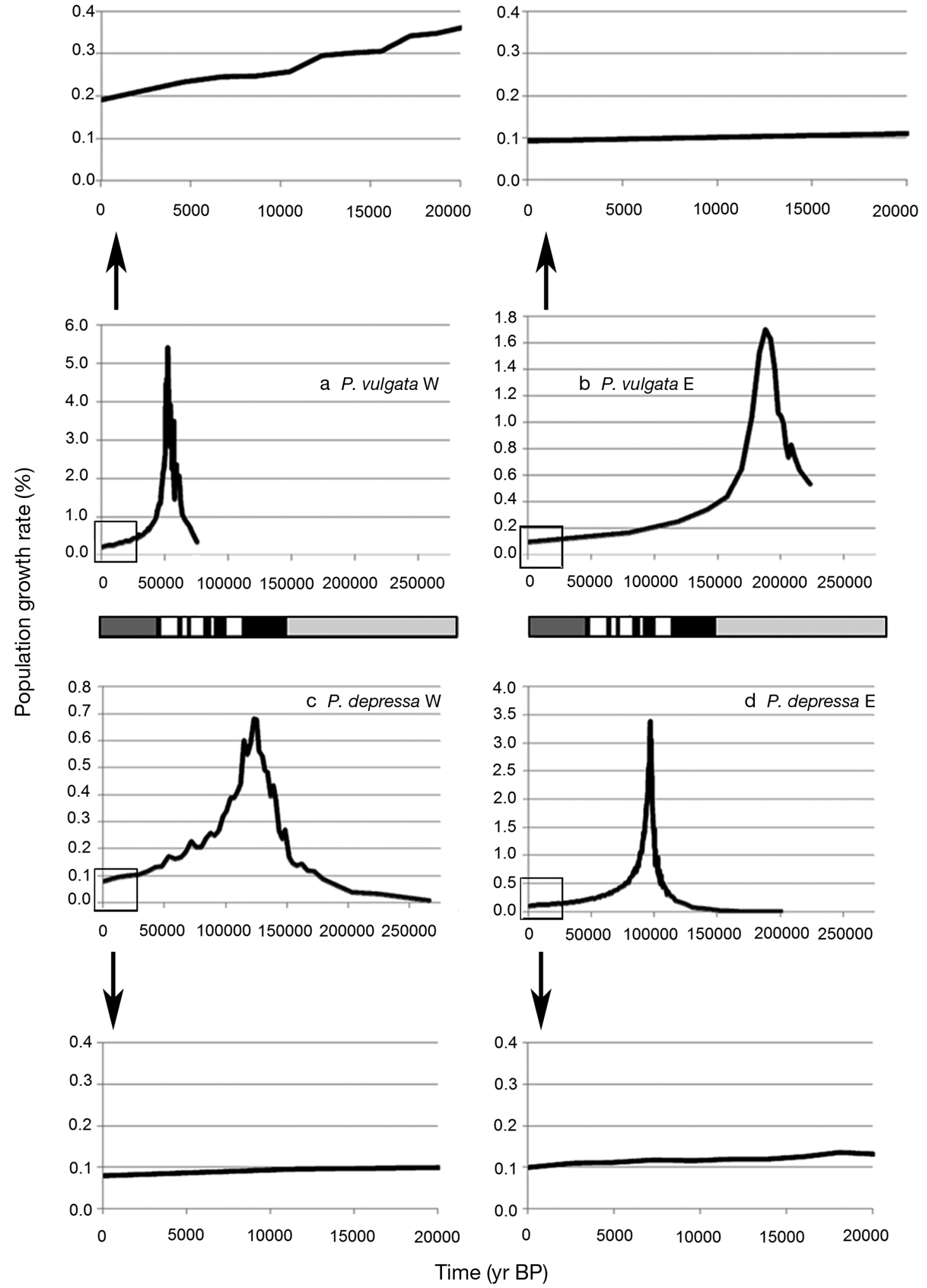

Fig. 5. Population growth rates over time for each species east (E) and west (W) of Cape Peñas (Asturias, Northern Spain). (a) Patella vulgata W, (b) Patella vulgata E, (c) Patella depressa W and (d) Patella depressa E. Enlarged plots correspond to the squares in the main graphs and show the growth rate over the last 20000 yr. Palaeoclimatic data (Pailler \& Bard 2002, Sánchez-Goñi et al. 2008) see grey scale: white $=$ cold, black $=$ warm; dark grey $=$ rapid temperature changes; light grey $=$ cold periods with warm peaks 
conditions may have adverse effects on the survival of juveniles and larvae as well as on the recruitment to the adult population of the species considered here (Southward et al. 1995). In addition, intraspecific competition is one of the main forces that shape limpet populations. The number of individuals of each species at each point may be determined by intense intraspecific competition rather than by interspecific competition (Boaventura et al. 2002). Intraspecific competition would be enhanced for stressed species under suboptimal environmental conditions, such as higher temperatures in the east and lower temperatures in the west (less preferred by Patella vulgata and P. depressa, respectively). Demographic growth would consequently decrease and do so more intensely for the more stressed species.

Human populations, in contrast, have increased their consumption of marine species since the Upper Palaeolithic (e.g. Aura et al. 1998, Stiner 2001 Richards et al. 2005, Bicho \& Haws 2008). In the past, their impact would have been more pronounced in the eastern part of Asturias, where human settlements were more dense and abundant (Turrero et al. 2012). Traces of past exploitation may be reflected in smaller limpet sizes in eastern zones (Table 2) as a consequence of the selective harvesting of bigger specimens (e.g. Morales et al. 1998, Stiner et al. 1999, Turrero et al. 2012). This likely accelerated the process of species substitution since Patella vulgata is larger than $P$. depressa and would be harvested preferentially. However, harvesting is not necessarily the only factor affecting limpet size. Larger size is correlated to lower water temperature in invertebrates, so a concomitant effect of lower temperatures and less intense harvesting might explain the larger sizes in the west. At the population-genetics level, intense exploitation would produce more drastic bottlenecks and diversity reductions in the more exploited species, P. vulgata in our study area (e.g. Borrell et al. 2010, Turrero et al. 2012). This would be reflected in its star-shaped haplotype network, indicating past bottlenecks (e.g. Mirol et al. 2008). Therefore, east of Cape Peñas, 2 causes would contribute to $P$. vulgata declines: harvesting and warming. The same 2 causes would be less pronounced to the west, where the species shows higher genetic diversity (Fig. 4). In contrast, $P$. depressa may have expanded along with the warming (Hawkins et al. 2008), contributing to generate the current pattern of relative abundance and genetic diversity of the 2 species at the 2 sides of Cape Peñas. Its past bottlenecks could have occurred during previous cold periods, without excluding past harvesting as in P. vulgata.
As seen above, many factors could be invoked to explain the population trends of these 2 limpet species found in North Iberia. As in other invertebrates (Erasmus et al. 2002), climate seems to be a key factor of limpet abundance and distribution (Helmuth et al. 2006, Hawkins et al. 2008). Fluctuating environmental conditions (Southward et al. 1995), intraspecific competition (Boaventura et al. 2002) and human harvesting (Morales et al. 1998, Stiner et al. 1999, Turrero et al. 2012) would also account for sustained declines in these species' demographic growth during the last millennia.

Along the coast of Asturias, Patella depressa is more abundant than $P$. vulgata in the warmer eastern area, and this relationship is reverted in the cooler western zone. This distribution is in agreement with the respective optimal temperatures for reproduction of these 2 species. Coalescent analyses of mitochondrial DNA sequences revealed population expansions coincident with climate changes in the last 250000 yr: warm and cold temperatures would have favoured the expansion of $P$. depressa and P. vulgata, respectively. Human exploitation in the last $20000 \mathrm{yr}$ may have caused differences in size between the eastern and western populations by selective harvesting of larger limpets. Climate seems to have been decisive for population growth at large time scales, while human exploitation would have contributed to produce bottlenecks and morphological changes at a smaller and more recent temporal scale.

Acknowledgements. We are grateful to I. Pola for his help with laboratory tasks. M.M.-C. holds a National Spanish Grant (reference AP-2010-5211) and P.T. holds a grant from Plan de Ciencia Tecnología e Innovación-Programa Regional de Asturias RTD (reference BP08-077). This work was supported by the Spanish project CGL2009-08279.

\section{LITERATURE CITED}

Acker JG, Leptoukh G (2007) Online analysis enhances use of NASA Earth science data. EOS Trans Am Geophys Union 88:14

AEMET (Agencia Estatal de Meteorología) (2005) Guía resumida del clima en España 1971-2000: plan estadístico nacional 2001-2004. Ministerio de Medio Ambiente, Madrid

Arias Cabal P, Fernández-Tresguerres Velasco JA, Álvarez Fernández E, Armendáriz Gutiérrez Á and others (2007) Excavación arqueológica de urgencia en la Cueva de la Poza l'Egua (Lledías, Llanes). In: Servicio de Publicaciones del Principado de Asturias (eds) Excavaciones arqueológicas en Asturias 1999-2002. Consejería de Cultura, Oviedo

Aura JE, Villaverde V, González Morales M, González Sainz C, Zilhão J, Straus LG (1998) The Pleistocene-Holocene 
transition in the Iberian Peninsula: continuity and change in human adaptations. Quat Int 49-50:87-103

Bicho N, Haws J (2008) At the land's end: marine resources and the importance of fluctuations in the coastline in the prehistoric hunter-gatherer economy of Portugal. Quat Sci Rev 27:2166-2175

Boaventura D, Cancela da Fonseca L, Hawkins SJ (2002) Analysis of competitive interactions between the limpets Patella depressa Pennant and Patella vulgata L. on the northern coast of Portugal. J Exp Mar Biol Ecol 271:171-188

Borrell YJ, Romano F, Vázquez E, Blanco G, Sanchez Prado JA (2010) DNA barcoding and phylogeny of Patellids from Asturias (Northern Spain). In: Nimis PL, Lebbe RV (eds) Tools for identifying biodiversity: progress and problems. EUT Edizioni Università di Trieste, p 281-287

Bowman RS, Lewis JR (1986) Geographical variation in the breeding cycles and recruitment of Patella ssp. Hydrobiologia 142:41-56

> Calderon I, Giribet G, Turon X (2008) Two markers and one history: phylogeography of the edible common sea urchin Paracentrotus lividus in the Lusitanian region. Mar Biol 154:137-151

Christiaens J (1973) Révision du genre Patella (Mollusca, Gastropoda). Bull Mus Hist Natl Hist Paris 182:1305-1392

> Davis BAS, Brewer S, Stevenson AC, Guiot J, data contributors (2003) The temperature of Europe during the Holocene reconstructed from pollen data. Quat Sci Rev 22: 1701-1716

Dawson TP, Jackson ST, House JI, Prentice IC, Mace GM (2011) Beyond predictions: biodiversity conservation in a changing climate. Science 332:53-58

de Abreu L, Shackleton NJ, Shönfeld J, Hall M, Chapman M (2003) Millennial-scale oceanic climate variability off the Iberian Western margin during the last two glacial periods. Mar Geol 196:1-20

Dickson RR, Hughes DG (1981) Satellite evidence of mesoscale eddy activity over the Biscay abyssal plain. Oceanol Acta 4:43-46

> Drummond AJ, Rambaut A (2007) BEAST: Bayesian evolutionary analysis by sampling trees. BMC Evol Biol 7:214

Erasmus BFN, Van Jaarsveld AS, Chown SL, Kshatriya M, Wessels KJ (2002) Vulnerability of South African animal taxa to climate change. Glob Change Biol 8:679-693

Estoup A, Largiadér CR, Perrot E, Chourrout D (1996) Rapid one tube DNA extraction for reliable PCR detection of fish polymorphic markers and transgenes. Mol Mar Biol Biotechnol 5:295-298

Excoffier L, Laval G, Schneider S (2005) Arlequin ver. 3.0: an integrated software package for population genetics data analysis. Evol Bioinform 1:47-50

Folmer O, Black M, Hoeh W, Lutz R, Vrijenhoek R (1994) DNA primers for amplification of mitochondrial cytochrome c oxidase subunit I from diverse metazoan invertebrates. Mol Mar Biol Biotechnol 3:294-299

Fretter V, Graham A (1976) The prosobranch molluscs of Britain and Denmark: I. Pleurotomariacea, Fissurellacea and Patellacea. J Molluscan Stud Suppl 1:1-37

Gross L (2011) Climate change could change rates of evolution. PLoS Biol 9:e1001015

> Gutiérrez-Zugasti I (2011) Coastal resource intensification across the Pleistocene-Holocene transition in Northern Spain: evidence from shell size and age distributions of marine gastropods. Quat Int 244:54-66

Hall TA (1999) BioEdit: a user-friendly biological sequence alignment editor and analysis program for Windows 95/98/NT. Nucleic Acids Symp Ser 41:95-98

Hawkins SJ, Moore PJ, Burrows MT, Poloczanska E and others (2008) Complex interactions in a rapidly changing world: responses of rocky shore communities to recent climate change. Clim Res 37:123-133

Helmuth B, Mieszkowska N, Moore P, Hawkins SJ (2006) Living on the edge of two changing worlds: forecasting the responses of rocky intertidal ecosystems to climate change. Annu Rev Ecol Syst 37:373-404

Herbert RJH, Hawkins SJ, Sheader M, Southward AJ (2003) Range extension and reproduction of the barnacle Balanus perforatus in the eastern English Channel. J Mar Biol Assoc UK 83:73-82

> Herbert RJH, Southward AJ, Sheader M, Hawkins SJ (2007) Influence of recruitment and temperature on distribution of intertidal barnacles in the English Channel. J Mar Biol Assoc UK 87:487-499

> Horreo JL, Machado-Schiaffino G, Ayllon F, Griffiths AM, Bright D, Stevens JR, Garcia-Vazquez E (2011) Impact of climate change and human-mediated introgression on South European Atlantic salmon populations. Glob Change Biol 17:1778-1787

Johnson MS, Black R (1984) The Wahlund effect and the geographical scale in the intertidal limpet Siphonaria. Mar Biol 79:295-302

> Koufopanou V, Reid DG, Ridgway SA, Thomas RH (1999) A molecular phylogeny of the Patellid limpets (Gastropoda: Patellidae) and its implications for the origins of their antitropical distribution. Mol Phylogenet Evol 11: 138-156

> Librado P, Rozas J (2009) DnaSP v5: a software for comprehensive analysis of DNA polymorphism data. Bioinformatics 25:1451-1452

> Lima FP, Queiroz N, Ribeiro PA, Hawkins SJ, Santos AM (2006) Geographic expansion of a marine gastropod, Patella rustica Linnaeus, 1758, and its relation with usual climatic events. J Biogeogr 33:812-822

Lima FP, Ribeiro PA, Queiroz N, Hawkins SJ, Santos AM (2007) Do distributional shifts of northern and southern species of algae match the warming pattern? Glob Change Biol 13:2592-2604

Mannino MA, Thomas KD (2002) Depletion of a resource? The impact of prehistoric human foraging on intertidal mollusc communities and its significance for human settlement, mobility and dispersal. World Archaeol 33: 452-474

Mieszkowska N, Leaper R, Moore P, Kendall MA and others (2005) Marine biodiversity and climate change: assessing and predicting the influence of climatic change using intertidal rocky shore biota. Occas Pub Mar Biol Assoc UK 20

> Mirol PM, Routtu J, Hoikkala A, Butin RK (2008) Signals of demographic expansion in Drosophila virilis. BMC Evol Biol 8:59

Moore PJ, Thompson RC, Hawkins SJ (2011) Phenological changes in intertidal con-specific gastropods in response to climate warming. Glob Change Biol 17:709-719

- Morales A, Roselló E, Hernández F (1998) Late Upper Palaeolithic subsistence strategies in Southern Iberia: tardiglacial faunas from Cueva de Nerja (Málaga, Spain). Eur J Archaeol 1:9-50

- Myers RA, Worm B (2003) Rapid worldwide depletion of predatory fish communities. Nature 423:280-283

Ortea J (1986) The malacology of La Riera Cave. In: Straus 
LG, Clark GA (eds) La Riera Cave: Stone Age huntergatherers in Northern Spain. Anthropological Research Papers, No. 36. Arizona State University, p 289-298

Orton JH, Southward AJ, Dodd JM (1956) Studies on the biology of limpets. II. The breeding of Patella vulgata L. in Britain. J Mar Biol Assoc UK 35:149-176

Pailler D, Bard E (2002) High frequency palaeoceanographic changes during the past 140000 yr recorded by the organic matter in sediments of the Iberian Margin. Palaeogeogr Palaeoclimatol Palaeoecol 181: 431-452

Parmesan C (2006) Ecological and evolutionary responses to recent climate change. Annu Rev Ecol Evol Syst 37: 637-669

Posada D (2008) jModelTest: phylogenetic model averaging. Mol Biol Evol 25:1253-1256

Rambaut A, Drummond A (2007). Tracer version 1.4. http:// tree.bio.ed.ac.uk/software/tracer

Ribeiro PA, Branco M, Hawkins SJ, Santos AM (2010) Recent changes in the distribution of a marine gastropod, Patella rustica, across the Iberian Atlantic coast did not result in diminished genetic diversity or increased connectivity. J Biogeogr 37:1782-1796

Richards MP, Jacobi R, Cook J, Pettitt PB, Stringer CB (2005) Isotope evidence for the intensive use of marine foods by Late Upper Paleolithic humans. J Hum Evol 49:390-394

Ridgway SA, Reid DG, Taylor JD, Branch GM, Hodgson AN (1998) A cladistic phylogeny of the family Patellidae (Mollusca: Gastropoda). Philos Trans R Soc Lond B 353: 1645-1671

Rios A, Fraga F, Figueras FG, Prego R, Perez FF (1987) Campañas oceanográficas Asturias I, II, III y IV. Datos Inf 22: $1-140$

Sá-Pinto A, Branco M, Harris DJ, Alexandrino P (2005) Phylogeny and phylogeography of the genus Patella based on mitochondrial DNA sequence data. J Exp Mar Biol Ecol 325:95-110

Sánchez-Goñi MF, Landais A, Fletcher WJ, Naughton F, Desprat S, Duprat J (2008) Contrasting impacts of Dansgaard-Oeschger events over a western European latitudinal transect modulated by orbital parameters. Quat Sci Rev 27:1136-1151

Sella G, Robotti CA, Biglione V (1993) Genetic divergence among three sympatric species of Mediterranean Patella (Archaeogastropoda). Mar Biol 115:401-405

Southward AJ, Hawkins SJ, Burrows MT (1995) Seventy years' observations of changes in distribution and abundance of zooplankton and intertidal organisms in the western English Channel in relation to rising sea temperature. J Therm Biol 20:127-155

Editorial responsibility: Christine Paetzold, Oldendorf/Luhe, Germany
Stiner MC (2001) Thirty years on the 'Broad Spectrum Revolution' and Paleolithic demography. Proc Natl Acad Sci USA 98:6993-6996

Stiner MC, Munro ND, Surovell TA, Tchernov E, Bar-Yosef O (1999) Palaeolithic population growth pulses evidenced by small animal exploitation. Science 283: 190-194

Swofford DL (2003) PAUP. Phylogenetic analysis using parsimony ( ${ }^{*}$ and other methods), Version 4. Sinauer Associates, Sunderland, MA

Tamura K, Peterson D, Peterson N, Stecher G, Nei M, Kumar S (2011) MEGA5: molecular evolutionary genetics analysis using maximum likelihood, evolutionary distance, and maximum parsimony methods. Mol Biol Evol 28: 2731-2739

Thomas CD, Cameron A, Green RE, Bakkenes M and others (2004) Extinction risk from climate change. Nature 427: 145-148

Toucanne S, Zaragosi S, Bourillet JF, Gibbard PL and others (2009) A 1.2 Ma record of glaciations and fluvial discharge from the West European Atlantic margin. Quat Sci Rev 28:2974-2981

Tsahar E, Izhaki I, Lev-Yadun S, Bar-Oz G (2009) Distribution and extinction of ungulates during the Holocene of the Southern Levant. PLoS ONE 4:e5316

Turrero P, Muñoz-Colmenero M, Pola IG, Arbizu M, GarciaVazquez E (2012) Morphological, demographic and genetic traces of Upper Palaeolithic human impact on limpet assemblages in North Iberia. J Quaternary Sci 27: 244-253

Valiente AG, Beall E, Garcia-Vazquez E (2010) Population genetics of south European Atlantic salmon under global change. Glob Change Biol 16:36-47

Vonnemann V, Schrödl M, Klussmann-Kolb A, Wägele H (2005) Reconstruction of the phylogeny of the Opisthobranchia (Mollusca: Gastropoda) by means of $18 \mathrm{~S}$ and 28S rRNA gene sequences. J Molluscan Stud 71:113-125

> Ward P, Myers RA (2005) Shifts in open-ocean fish communities coinciding with the commencement of commercial fishing. Ecology 86:835-847

> Wilson RJ, Gutiérrez D, Gutiérrez J, Monserrat VJ (2007) An elevational shift in butterfly species richness and composition accompanying recent climate change. Glob Change Biol 13:1873-1887

> Wing SR, Wing ES (2001) Prehistoric fisheries in the Caribbean. Coral Reefs 20:1-8

Yoder AD, Irwin JA, Payseur BA (2001) Failure of the ILD to determine data combinability for slow loris phylogeny. Syst Biol 50:408-424

Submitted: January 16, 2012; Accepted: June 22, 2012 Proofs received from author(s): September 27, 2012 